\title{
Kenya: Begin community dialogue on FGM/C by discussing cultural justification
}

Frontiers in Reproductive Health

Follow this and additional works at: https://knowledgecommons.popcouncil.org/departments_sbsr-rh

Part of the Demography, Population, and Ecology Commons, Family, Life Course, and Society Commons, International Public Health Commons, Medicine and Health Commons, Sociology of Culture Commons, and the Women's Health Commons

How does access to this work benefit you? Let us know!

\section{Recommended Citation}

"Kenya: Begin community dialogue on FGM/C by discussing cultural justification," FRONTIERS OR Summary no. 59. Washington, DC: Population Council, 2007. 
Kenya
FGM/C

OR Summary 59

\section{Begin Community Dialogue on FGM/C by Discussing Cultural Justification}

Female genital cutting is strongly supported among the Somali community, and the severest form is primarily practiced. Efforts to encourage abandonment should begin with community discussion about the sociocultural reasons for cutting. Simultaneously, health care providers need training in how to manage the complications of FGM/C.

\section{Background}

The Somali ethnic community, including those living in Kenya, primarily practices infibulation, the most severe type of female genital mutilation/ cutting $(\mathrm{FGM} / \mathrm{C})$ in which the external female genitalia are removed and the remaining tissue is stitched or glued closed with a natural substance, leaving a small opening for the passage of urine and menstrual blood. This type of cut is associated with increased incidence and seriousness of obstetric and gynecological problems relative to uncut women and those with less severe forms of $\mathrm{FGM} / \mathrm{C}$.

\section{In 2004 FRONTIERS collaborated with UNICEF} on a four-month diagnostic study on FGM/C practices among the Somali community in Kenya. The study, undertaken in eastern Nairobi and North Eastern Province, sought to better understand the community's perception and practice of FGM/C, determine approaches to encourage its abandonment, and identify how the health system could be more actively engaged in managing complications and discouraging the practice.

Data were gathered through interviews and focus group discussions with community and religious leaders, married and unmarried men and women, 44 health care providers, and 101 antenatal clients who had been cut, as well as a rapid assessment of the readiness of 14 public and private clinics in the study region to offer safe motherhood services and manage FGM/C-related complications.

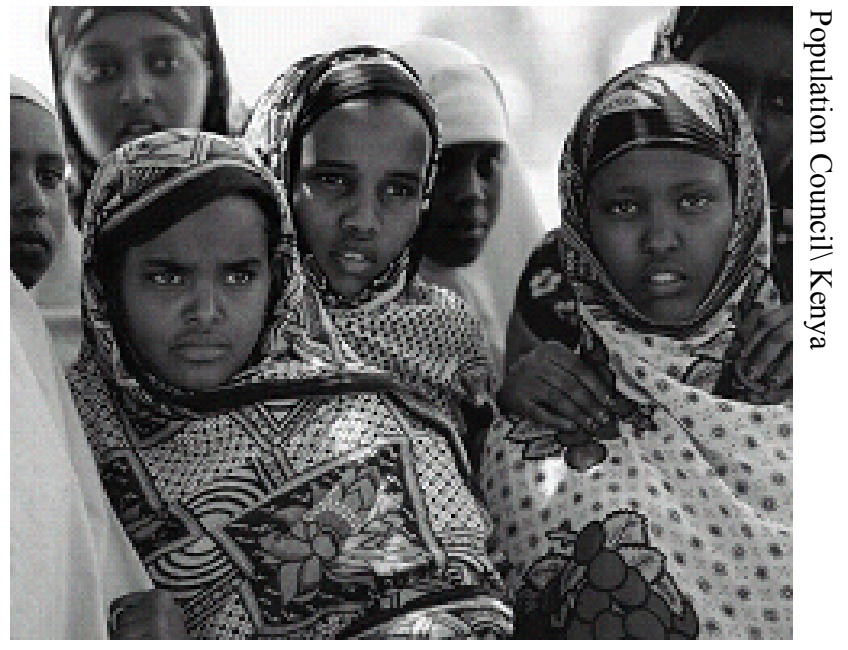

Support for FGM/C is very strong among Somalis.

\section{Findings}

Community perception: Support for FGM/C is very strong in the Somali community. All participating women and girls had been cut, and most were infibulated, though providers reported a gradual decline in the severity of the cut among younger girls. Major cultural factors affecting the practice include the following:

- Justifications for cutting included religious obligation, family honor, preserving virginity as a prerequisite for marriage, prevention of extramarital as well as premarital sex, and aesthetics. $\mathrm{FGM} / \mathrm{C}$ is not used as an initiation rite; most of the antenatal clients interviewed reported that they were cut before age 10 . 
- Many community members believed that Islam requires $\mathrm{FGM} / \mathrm{C}$, but religious leaders varied. Some viewed the practice as a violation of human rights and Islamic dictates; others said that the mother's rights and wishes determined cutting. Participants said that religious leaders could wield strong influence on abandonment of FGM/C.

- Family beliefs strongly affect the continuation of the practice. Mothers and grandmothers act as the principal decisionmakers regarding cutting, though fathers must also give their consent. Girls are never asked for their consent.

- Many community members felt that the movement to encourage abandonment of $\mathrm{FGM} / \mathrm{C}$ was driven by western interests and was part of a drive against traditional culture.

Medical care: This is a sparsely populated region with few health centers. Access to health care for cut women, including pregnant women, is limited even in areas where infibulation is nearly universal. This impedes medical management of FGM/ C, especially outside urban areas.

- Health facilities in North Eastern Province are poorly prepared to furnish safe motherhood services and even less prepared to care for infibulated pregnant women. All the facilities in Nairobi had sufficient personnel, training, and equipment to provide essential obstetric care; but none of the facilities in North Eastern Province could do so.

- Counseling for infibulated ANC clients is limited. Less than one-fifth had received birth-planning information related to their infibulation, including potential delivery problems or discussion of whether or not to re-infibulate after delivery.
- Women reported that cutting was mainly done by traditional practitioners. However, in Nairobi, health workers are increasingly being approached to perform infibulation and re-infibulations, indicating a trend towards medicalization of the practice. All equipment is easily available, including blades, local anesthesia, catgut sutures, and antibiotics.

\section{Utilization}

- FRONTIERS and the Kenyan Ministry of Health used findings from this study to develop training that improves safe motherhood care generally in North Eastern Province, and with a specific focus on managing complications associated with FGM/C. FRONTIERS is now collaborating with UNICEF, GTZ and CARE to develop and implement approaches to address uncertainty about the religious justification for the practice by stimulating dialogue among Islamic leaders and scholars.

\section{Policy Implications}

- In communities where FGM/C is strongly supported and movements to encourage its abandonment are suspect, interventions need to ensure the explicit support of political, religious, and other cultural leaders to counter these perceptions. Addressing the belief that $\mathrm{FGM} / \mathrm{C}$ is a religious requirement is a crucial first step, given the uncertainty and range of interpretations concerning Islamic guidance on the issue.

- Where severe forms of cutting are common, pre-service training for health providers should include orientation on $\mathrm{FGM} / \mathrm{C}$ and management of its complications, as well as training on ethical issues in medical treatment.

Source: Jaldesa, Guyo W., Ian Askew, Carolyne Njue, and Monica Wanjiru. 2005. "Female genital cutting among the Somali of Kenya and management of its complications," FRONTIERS Final Report. Washington, DC: Population Council. Available on our website at www. popcouncil.org/frontiers/frontiersfinalrpts.html or by e-mail:frontiers@pcdc.org

This publication is made possible by the generous support of the American people through the United States Agency for International Development (USAID) under the terms of Cooperative Agreement No. HRN-A-00-98-00012-00. The contents are the responsibility of the FRONTIERS Program and do not necessarily reflect the views of USAID or the United States Government. 